\title{
Fiscal policies, social spending and economic performance in France, Germany and the UK since 1970
}

\author{
Norman Flynn
}

\section{Introduction}

This chapter looks at the post-1970 development of social policy, its fiscal implications and economic consequences in three European countries. Its purpose is to test a stereotypical 'left' proposition, formulated in defence of European social democracy against neo-liberalism, such as:

There is a 'European Social Model', incorporating a high level of social protection for unemployment and retirement, which, since 1973, has been threatened by various 'fiscal crises' and pressures from demographic changes, especially falling birth rates and increased longevity and from economic competition. Recent elections in Germany and France have ushered in governments determined to undermine the European model and replace it with a deregulated economy and unprotected workforce.

All parts of this stereotypical statement have credible negatives. The 'Europeanness' of welfare policy is neither sufficiently homogeneous (displaying big differences between countries and probably excluding some Mediterranean countries) nor sufficiently distinct, unless set against a small set of 'others' and including various similar non-European welfare regimes, including Australia, New Zealand, Canada and probably Japan. Even a relatively small group of 'European' welfare states has a wide variety of origins and characteristics. To defend a European style of welfare regime against a neo-liberal style is therefore to defend variety.

Fiscal pressures have followed the economic cycle, although possibly with growing amplitude, and have not yet resulted in an overall crisis, if such is defined as a failure or breakdown. Periodically, governments have been elected who try to reverse public spending growth and redesign welfare systems, whether in Scandinavia and the UK at the beginning of the 1980s, the Kohl governments in Germany through the 1980s and the Merkel government from 2005, or Sarkozy as Finance Minister and 
then President in France in 2007. Only the UK's Conservatives succeeded in producing a residualised state welfare system, especially in the areas of retirement pensions and unemployment compensation: the others have gradually increased retirement ages, reduced the generosity of benefits and tried to reduce the costs of unemployment compensation.

European economies are subject to shared competitive pressure, but have responded in different ways. Of the three major economies, Germany has gradually dismantled its consensual corporatism as companies swing towards shareholder returns and away from social responsibility and France has also slowly liberalised. Only the UK has created a liberal labour market and weak regulation. However, on economic indicators of national economic success, such as the competitiveness of exports, or labour productivity, France and Germany are consistently outperforming the UK, which survives on low productivity, long working hours and balance of payments deficits.

\section{Selective solidarity, corporatism and state welfare}

One of the difficulties in arguing for a 'European' model of social welfare provision is Europe's diversity. Gosta Esping-Andersen (1990) made an influential classification of OECD-member welfare regimes, which divided the world into three - the social democratic welfare state, the liberal democratic and the conservative corporatist. The UK was put in the liberal democratic camp, with France and Germany in the conservative corporatist. For our purposes, analysing differences, it is important to look at the differences between France and Germany as well as the similarities.

\section{Germany}

There is no doubt that Germany's pension, unemployment benefit and healthcare systems are generous by world standards. While the rhetoric of the critics may be exaggerated, since Konrad Adenauer's chancellorship, German citizens have benefited from high levels of benefits and have paid high levels of tax for them. Some commentators say that the scale and reach of the welfare state is unsustainable. The Süddeutsche Zeitung summarised this position:

The first German Chancellor (Bismarck) reacted to the old, rural welfare system that was partly family, partly feudal with a solution for the new citydwelling industrial working class. Sickness, accident and unemployment insurance would prevent the creation of a forgotten lumpen proletariat and undermine the basis for social revolution and coups.

The kernel of Bismarck's social policy was the insurance principle: participants in the labour process put a small share of their wages into a big welfare 
chest from which any needs would be met by a guaranteed payment of the claim.

The next radical effort needed another big Chancellor, Konrad Adenauer. After the Second World War he proved himself to be the protector of German solidarity with an astonishing expansion of access to compensation by guaranteeing wealth to those excluded from the consumer economy. At the height of the economic miracle, Adenauer converted the principle of 'burden sharing' to the principle of 'wealth sharing', setting up transfer mechanisms whereby pensioners and the unemployed share the general wealth of the country ... What Schröder and his people have begun is nothing less than leading the German welfare state from wealth-sharing to poverty-sharing. ${ }^{1}$ For future generations this welfare state must go back to its original purpose: insurance against the risk of basic hardships. ${ }^{2}$

There is a widespread view in Germany that the tax and benefit systems are in need of radical change and that the budget deficit will not be eradicated by future economic upturns. A thorough analysis appears in Kitschelt and Streeck (2004). The outline of the argument is this: the 'German system', a corporatist agreement on pay levels and company governance combined with high taxation and high levels of benefits, is under threat. Increasing openness of the economy makes it less possible for German companies to compete while absorbing high wages and the heavy tax and insurance contributions demanded by the welfare system. Trade union strength is waning and workers find it decreasingly possible to assert their welfare demands. Corporate governance has changed from a corporatist attitude, treating workers evenly with shareholders, towards objectives purely aimed at increasing profits and shareholder value.

At the same time, five factors have produced extra demands on the welfare and pension system: the longer than expected recession that generated high levels of unemployment; increasing profitability has been achieved by shedding labour, especially among the older workforce, who are entitled to pensions; demographic change also generates increasing pension demands; reunification was expensive as western levels of benefit entitlement were extended to the east while privatisation and exposure to competition produced a big increase in unemployment there.

These extra demands on the government's finances were met mainly by increases in the social security contributions of employers and employees and by borrowing. Unfortunately reunification was achieved at the start of a recession that depressed tax revenues.

The first Schröder Government (1998-2002) reversed some of the cuts in pensions, sick pay and disability benefits that the Kohl government had implemented. It also tried to make some cuts of its own, most notably in the replacement rate of the standard public pension, from 70 per cent to 
64 per cent by 2030 . At the beginning of its second term the government introduced the first of the so-called Hartz reforms to the labour market. Peter Hartz, personnel director of Volkswagen, chaired a commission to propose changes to the unemployment benefit system to try to reduce the disincentives for the unemployed to seek low-paid jobs. The reform (known as Hartz IV) involved changing the unemployment benefit system. Before Hartz IV unemployed people got 60 per cent of previous earnings (67 per cent for those with children) for thirty-two months, then 53-57 per cent for ever. Hartz IV does away with the second payment, replacing it with a flat-rate means-tested benefit of $€ 345$ per month plus a rent and heating allowance (€331 in the east). The new benefit is also conditional on claimants actively seeking work.

Hartz IV was part of a collection of policy shifts that were collected together at the end of 2003 in Agenda 2010, which contained changes in social welfare provision, taxation, education and training, research and labour market policies.

\section{France}

The French welfare state has its origins in the public medical insurance and pension scheme enacted in 1930. It was consolidated in 1945-46 and developed into a comprehensive and complicated welfare system. Families are the most important unit, receiving family benefits, child allowances and housing allowances. The family allowance, introduced in 1932, continued and was increased, partly because of concerns about falling birth rates and fears of an ageing population, and partly because of a policy designed to support nuclear families. Spending on family policy represents nearly half of social spending.

There is a mixture of insurance-based schemes for employees and state benefits for non-contributors. Pensions are state-backed but based on employer and employee contributions. The pension scheme has recently been under fiscal strain from early retirements and longevity. The main feature of the pension system is the existence of 'special funds' for occupational groups, such as transport workers and the professions in the public sector. About 30 per cent of the population is covered by one of the special funds, which absorb 60 per cent of France's pension costs. The thirty-six major special funds are all in deficit and subsidised by taxation. Successive French governments have tried to cut the spending on these subsidies, by increasing retirement ages and the number of years' contributions required before retirement pensions are paid. The reforms have been resisted by the unions representing the beneficiaries of these funds, which are embedded in their administration. Since 1995, there have been reform efforts and resistance, a process pursued by Juppé (1995-97), suspended during 
most of Lionel Jospin's term (1997-2002) and pursued again by Raffarin (2002-05) and then by Nicholas Sarkozy (2007-). Resistance to changes in the pension regimes is presented as 'solidaristic', despite the fact that the schemes themselves are exclusive (Smith 2004).

Workers' rights (especially the protection from dismissal and the 35-hour week) are also strong in France and there have been reform attempts and resistance over a long period (see Chapter 4 in this book). Some argue that the inflexibility of the labour market that results from these protections is a major cause of persistent high unemployment. There has been no concerted policy of reducing these rights equivalent to the Hartz proposals in Germany, although there are periodic efforts to change individual aspects, such as the 'first employment contract' changes proposed in 2006, which would have removed employment protection in the first two years' employment from workers under 25 years old, but was then dropped after mass protests.

\section{United Kingdom}

The welfare system in the UK has its origins in the Liberal governments of 1906-14, which introduced an unemployment insurance scheme and mutual health insurance societies. The health and unemployment insurance systems were consolidated at the end of the Second World War, providing a universal, free healthcare system, a universal state pension and unemployment benefits. While there is a National Insurance contribution by employers and employees, in practice these are treated exactly like other taxes and constitute a payroll tax. There is a universal pension at a flat rate, enhanced by an earning-related element for people who have paid National Insurance contributions. In practice, pensioners who have not paid contributions receive supplementary income and rent subsidy because the basic pension is so low. The rate of increase of pensions was pegged to inflation rather than incomes in the early 1980s and its real value eroded.

Unemployment benefits are time-limited to six months and are conditional on active job-seeking (the benefit is called 'Jobseeker's Allowance'). The long-term unemployed enter the social security system and also have to seek work and training. The health system is free at the point of use for most services (excluding dentistry) although a charge is made for drugs.

Conservative governments from 1979-97 made various attempts to cut public spending and reduce the scope of the state. Public housing was privatised by selling homes to tenants. State pensions were frozen in real terms to contain cost and to encourage people to make their own individual or company pension provision. The privatisation programme removed about two million workers, in nationalised industries, the 'industrial civil service' and public transport, from state-backed pension schemes. Various efforts 
were made to increase the incentive to work and increase the gap between incomes in low-paid jobs and on benefits.

The Labour governments from 1997 continued the 'welfare to work' changes to benefits, by introducing a tax credit for low-paid working families and increasing child allowances, further enhancing the incentive for unemployed people to take jobs even if they are low paid. Pensions were unpegged from inflation. From 1999-2007, government spending policy was expansionary, increasing capital spending to cover the backlog of building and maintenance, especially of hospitals and schools, and increasing service improvements, especially in healthcare and education. In the case of healthcare an explicit target of spending as a percentage of GDP was adopted to bring healthcare standards up to European levels.

\section{Comparing social spending}

Given the difference in unemployment rates and social policies among France, Germany and the UK, it might be supposed that the expenditure on 'social expenditure' would show big variations, and especially would be much higher in the high unemployment countries. Table 2.1 shows social expenditure and its components as a percentage of GDP in 1981, 1991 and 2001.

Table 2.1 shows that the UK social expenditure is 5 to 6 percentage points of GDP below France and Germany. The categories on which the UK spends less are health, unemployment and old age. The differences in health spending are easily explained: in France and Germany there are 3.3 doctors per 1,000 population while the UK has 2.1, with commensurate differences in associated health spending. ${ }^{3}$

If we look at unemployment benefits, we see that the French and German systems are more generous to unemployed people, especially in the first year of their unemployment. Table 2.2 summarises the unemployment benefits in the three countries and Table 2.3 shows the unemployment insurance rates.

It is clear that the salary-related unemployment benefits in France and Germany are more generous than the flat-rate payments in the UK and that the period over which benefits are paid are longer than the UK's six months. Both the French and German governments have expressed concern about the 'poverty trap', whereby there is only a small incentive for unemployed people to look for work because the difference in net income between benefits and salary is so small. To some extent the UK government ameliorated this incentive problem by maintaining some benefits for low-paid workers if they return to work after being unemployed. The "working families tax credit' that guarantees a minimum income for low-paid working parents gives people with children an incentive to take low-paid jobs. Reducing 
Table 2.1 Public social expenditure 1981-2001, as a percentage of GDP

\begin{tabular}{|c|c|c|c|c|}
\hline$\%$ of GDP & & 1981 & 1991 & 2001 \\
\hline \multirow[t]{3}{*}{ Total social expenditure } & UK & 19.5 & 21.1 & 21.8 \\
\hline & France & 22.2 & 27.2 & 28.5 \\
\hline & Germany & 23.7 & 24.9 & 27.4 \\
\hline \multirow[t]{3}{*}{ Old age } & UK & 6 & 7.8 & 8.1 \\
\hline & France & 8 & 9.6 & 10.6 \\
\hline & Germany & 10.1 & 10 & 11.7 \\
\hline \multirow[t]{3}{*}{ Survivors } & UK & 1.8 & 0.7 & 0.6 \\
\hline & France & 2 & 1.7 & 1.5 \\
\hline & Germany & 0.9 & 0.5 & 0.4 \\
\hline \multirow[t]{3}{*}{ Incapacity } & UK & 1.1 & 2.3 & 2.5 \\
\hline & France & 2.9 & 2.5 & 2.1 \\
\hline & Germany & 2.1 & 1.8 & 2.3 \\
\hline \multirow[t]{3}{*}{ Health } & UK & 5.2 & 5.3 & 6.1 \\
\hline & France & 6.1 & 6.7 & 7.2 \\
\hline & Germany & 7.1 & 7.1 & 8 \\
\hline \multirow[t]{3}{*}{ Family } & UK & 2.4 & 2.1 & 2.2 \\
\hline & France & 2.8 & 2.7 & 2.8 \\
\hline & Germany & 2.4 & 2 & 1.9 \\
\hline \multirow[t]{3}{*}{ Labour market } & UK & 0.6 & 0.5 & 2.2 \\
\hline & France & 0 & 0.9 & 2.8 \\
\hline & Germany & & 1.4 & 1.9 \\
\hline \multirow[t]{3}{*}{ Unemployment } & UK & 1.5 & 1 & 0.3 \\
\hline & France & 0 & 1.9 & 1.6 \\
\hline & Germany & 0.8 & 1.4 & 1.2 \\
\hline \multirow[t]{3}{*}{ Housing } & UK & 0.2 & 1.2 & 1.5 \\
\hline & France & 0.5 & 0.8 & 0.9 \\
\hline & Germany & 0.1 & 0.1 & 0.2 \\
\hline
\end{tabular}

Source: OECD database

the period over which unemployment benefits are paid to six months also encourages people back to work. The German government has reduced the period over which unemployment benefits are paid since the information in Table 2.2 was produced.

The OECD made a calculation of the net income difference for a typical working family between being unemployed and returning to work in 1999. The results are shown in Table 2.4. This information is given in GBP, FF and DM, as it was collected in the year before the introduction of the euro. A simplified way of expressing the relationship between earnings in work and earnings when unemployed is a single figure called the 'unemployment trap' (shown in Table 2.5). Eurostat defines this as follows: 'The unemployment trap measures what percentage of the gross earnings (from 
Table 2.2 Unemployment benefits (insurance system), 2002

\begin{tabular}{|c|c|c|c|c|}
\hline & Duration & Reference salary & Rate & Taxation \\
\hline UK & $\begin{array}{l}182 \text { days } \\
\text { maximum }\end{array}$ & $\begin{array}{l}\text { Lump-sum, } \\
\text { age-related }\end{array}$ & $\begin{array}{l}\text { Lump-sum, } \\
\text { age-related }\end{array}$ & Taxed \\
\hline France & $\begin{array}{l}\text { Age-related and } \\
\text { related to length } \\
\text { of employment; } \\
42 \text { months } \\
\text { maximum }\end{array}$ & $\begin{array}{l}\text { Average } \\
\text { monthly salary }\end{array}$ & $\begin{array}{l}\text { Fixed }+ \\
\text { proportional to } \\
\text { salary; } 57.4 \% \text { of } \\
\text { salary maximum }\end{array}$ & Taxed \\
\hline Germany & $\begin{array}{l}\text { Age-related and } \\
\text { related to length } \\
\text { of employment; } \\
32 \text { months } \\
\text { maximum }\end{array}$ & $\begin{array}{l}\text { Net average over } \\
\text { previous year; } \\
\text { ceiling }\end{array}$ & $\begin{array}{l}60 \% \text { of net } \\
\text { salary, } 67 \% \text { with } \\
\text { children }\end{array}$ & Not taxed \\
\hline
\end{tabular}

Source: Zoom 2003

Table 2.3 Unemployment insurance rates, 2002

\begin{tabular}{lcc}
\hline & $\begin{array}{c}\text { Payment rate as \% of } \\
\text { previous gross earnings }\end{array}$ & $\begin{array}{c}\text { Maximum benefit } \\
\text { (\$US terms) }\end{array}$ \\
\hline France & 76 & 60,184 \\
Germany & 60 & 30,890 \\
United Kingdom & Flat & 4,084 \\
\hline
\end{tabular}

Source: OECD Benefits and Wages Indicators, from OECD database (accessed 2002)

moving into employment) is "taxed away" by the combined effects of the withdrawal of benefits and higher tax and social security contributions' (Eurostat 2004). Table 2.5 is concerned with the bottom end of the labour market and shows the difference in tax treatment of low wages. Broadly it suggests that there is less incentive for an unemployed person to take a lowpaid job in Germany than in France and much less in France and Germany than in the UK. While there is no conclusive evidence that high marginal tax rates produce a disincentive to take low-paid jobs, government policy on benefits for the unemployed and net tax for the low paid are based on this idea in the UK, and increasingly so in France.

The difference between workers' take-home pay and what it costs to employ them, known as the 'tax wedge', consists of income tax and the socialsecurity contributions of employees and employers. Table 2.6 shows the tax wedge in 2003. The table shows the difference between take-home pay and the cost to employers at various ratios to the average productive wage. 


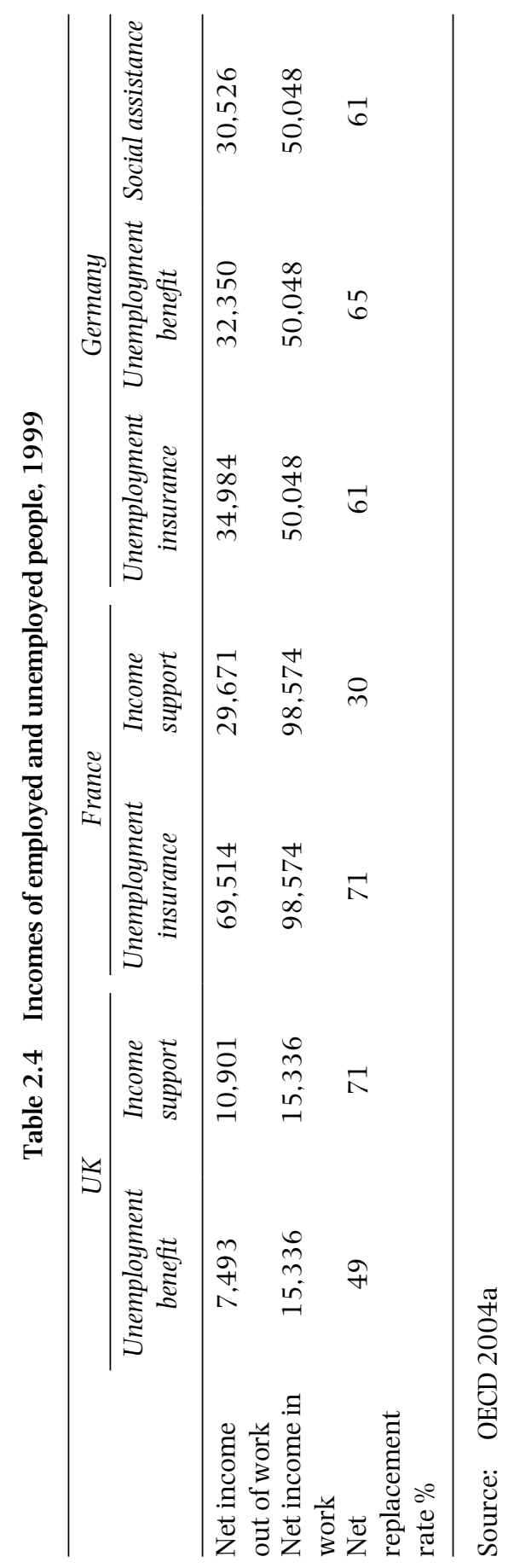


Table 2.5 Tax rate on low-wage earners: unemployment trap in 2002

\begin{tabular}{ccc}
\hline UK & France & Germany \\
\hline 71 & 83 & 87 \\
\hline
\end{tabular}

Source: Eurostat 2004: 146

Table 2.6 The tax wedge, 2003: marginal tax rates at income levels proportionate to the average productive wage

Total tax wedge 2003

\begin{tabular}{llrrr}
\hline \% of average productive wage & 67 & 100 & 133 & 167 \\
France & 74.1 & 52.5 & 53.8 & 53.8 \\
Germany & 59.8 & 65.3 & 61.5 & 67.4 \\
UK & 40.6 & 40.6 & 40.6 & 31.7 \\
\hline
\end{tabular}

Source: OECD database (accessed 2004)

Table 2.7 Unemployment as a percentage of the labour force, 2002-4

\begin{tabular}{cccc}
\hline & UK & France & Germany \\
\hline 2002 & 5.2 & 9.0 & 8.1 \\
2003 & 5.0 & 9.7 & 8.7 \\
2004 & 4.8 & 9.9 & 8.8 \\
\hline
\end{tabular}

Source: OECD 2004b

First, it is clear that employing relatively low-paid workers in France is an expensive undertaking. In Germany the bigger problem arises at the average and above average pay level. In the UK, with its cap on income tax and on social security contributions, the tax wedge is equal across the wage bands and lower than both France and Germany.

It is commonly said that the UK has a more flexible labour market than France and Germany. Payroll taxes are lower, firing is easier and therefore companies are more willing to hire labour. This results in lower rates of unemployment. It is certainly the case that unemployment rates are higher in France and Germany than in the UK. Table 2.7 shows comparative unemployment rates.

In Germany, the unemployment rate in the previous East German Länder is about twice the rate in the rest of the country.

\section{Public pensions}

Table 2.1 showed the difference in spending on old age. A large part of the explanation for this difference is the level of pensions as a proportion of 
Table 2.8 Pension ratios, 2000

\begin{tabular}{lcccc}
\hline & $\begin{array}{c}\text { Average pensioner } \\
\text { benefits: average } \\
\text { earnings }\end{array}$ & $\begin{array}{c}\text { Population } \\
\text { 65+:population } \\
16-64\end{array}$ & $\begin{array}{c}\text { Proportion of } \\
\text { 16-64-year-olds } \\
\text { working }\end{array}$ & $\begin{array}{c}\text { Pensioners per } \\
\text { worker }\end{array}$ \\
\hline France & 0.58 & 0.24 & 0.61 & 0.5 \\
Germany & 0.51 & 0.24 & 0.68 & 0.48 \\
UK & 0.20 & 0.24 & 0.73 & 0.4 \\
\hline
\end{tabular}

Source: Bongaarts 2004: Table 1

Table 2.9 Participation rates, 2002

\begin{tabular}{lccc}
\hline & UK & France & Germany \\
\hline Female & 65.3 & 56.7 & 58.8 \\
Male & 78.0 & 69.5 & 71.7 \\
Female 55-64 & 44.7 & 30.6 & 30.1 \\
Male 55-64 & 62.7 & 39.3 & 47.1 \\
\hline
\end{tabular}

Source: Metz et al. 2004

earnings. The UK ratio of pensioner benefits ${ }^{4}$ to average earnings in 2000 was 20 per cent while French and German pensioners received over half of average earnings. At that time there were no demographic differences, in the sense of the ratio of over-65-year-olds to those of working age. Table 2.8 shows the differences.

The difference in the dependency ratio arises from the employment levels among the working age population: early retirement in France and Germany has increased the ratio of pensioners per worker compared with the UK, rather than the age structure of the population. Table 2.9 shows participation rates (the percentage of the population who are either in work or seeking work) in the three countries in 2002.

The striking contrast is the higher participation rate of people aged 55 or over in the UK. A source of this difference in Germany is the shake-out as businesses sought to increase productivity from the mid-1980s on, combined with good levels of pension for the early retirers; in France, the generous pension system allows people to retire on good pensions after a relatively short working life.

What these snapshots of the three welfare systems show is that, on a world scale, the similarities among the three systems are more obvious than the differences: the settlement between labour and the state to provide tax and contribution funded social solidarity in old age and in periods of unemployment remains intact. The differences are in the levels 
of generosity of the solidarity payments, and in the conditions attached to such payments, given the differences in labour market regulation. The UK stands out as having a more flexible and less regulated labour market than the other two, while France has the most exclusive system of social solidarity and Germany has probably the most generous, especially to workers taking early retirement. These differences reflect the balance of power in the respective social democratic settlements: balanced towards the employers in the UK, to entrenched labour interests in France, and a residual corporatism in Germany, despite recent changes in government policy.

\section{Fiscal deficits, the economic cycle and crises}

National government budgets normally incur deficits at low points of the economic cycle, and many have persistent deficits. ${ }^{5}$ Some have "structural deficits', defined as the deficit at the top of the cycle: if tax revenues do not equal expenditure at the peak of the cycle, the deficit is more than cyclical. Structural deficits can result from consistent decisions to tax less than spending requires and from unanticipated expenditure requirements: unbudgeted for disasters such as floods, unplanned wars, and, in the case of Germany, the decision to reunite the country with a unified social welfare system and currency (the old 'East' Mark was given the value of the 'West' Mark). More gradual changes, such as the demographic effects of greater longevity and lower birth rates, can also lead to long-term deficits if commensurate adjustments to tax rates and entitlements are not made.

The Treaty of Maastricht of 1992 included provisions for harmonising the economic and monetary policies of EU member governments (articles 99-104). The four policy areas were: interest rates, inflation, government budget deficits and accumulated indebtedness. The Growth and Stability Pact (GSP) of July 1997 set out the maximum acceptable level of deficit for euro countries at 3 per cent of GDP, with the three non-euro EU members (UK, Denmark and Sweden) agreeing also to converge on this fiscal rule.

The idea of a common fiscal stance was pressed especially by the German government to try to instil some discipline in the taxation and spending policies of governments whose currencies had previously been less strong than the Deutsch Mark. In practice, several governments failed to comply with the rules: first Ireland, in 2002, and then Portugal, Germany and France. The pact was relaxed in March 2005. While the criteria of a maximum deficit of 3 per cent of GDP and maximum debt of 60 per cent of GDP remained in place, the rules were changed to allow exceptions to be tolerated and to not be met with sanctions. The exceptions include potential growth rates, the economic cycle, policies on pensions and social security, 
Table 2.10 Total tax revenue as a percentage of GDP, 1975-2003

\begin{tabular}{lccccccc}
\hline & 1975 & 1985 & 1995 & 2000 & 2001 & 2002 & 2003 \\
\hline UK & 35.3 & 37.7 & 35.0 & 37.4 & 37.2 & 35.8 & 35.3 \\
France & 35.9 & 43.8 & 43.9 & 45.2 & 44.2 & 44.0 & 44.2 \\
Germany & 35.3 & 37.2 & 38.2 & 37.8 & 36.8 & 36.0 & 36.2 \\
\hline
\end{tabular}

Source: Revenue Statistics 1965-2003, OECD 2004a: 18

Table 2.11 Taxes on income and profits as a percentage of GDP, 1975-2003

\begin{tabular}{lrrrrrrr}
\hline & 1975 & 1985 & 1995 & 2000 & 2001 & 2002 & 2003 \\
\hline UK & 15.8 & 14.6 & 12.8 & 14.6 & 14.7 & 13.5 & 12.9 \\
France & 5.7 & 7.0 & 7.1 & 11.2 & 11.3 & 10.5 & 10.2 \\
Germany & 12.1 & 12.9 & 11.6 & 11.4 & 10.6 & 10.1 & 9.9 \\
\hline
\end{tabular}

Source: Revenue Statistics 1965-2003, OECD 2004a: p.19

reforms and fiscal policy towards the management of debt levels over the cycle. While not abandoning the pact, the new agreement weakened its impact, to the extent that the Governing Council of the European Central Bank expressed serious concern over the future sustainability of public finances in the eurozone. It was an important recognition that budget balances are subject to cyclical and other influences.

Before looking at the reasons for the deficits in France and Germany, we look at the overall level of taxation in the three countries. Over the past three decades, there have been fairly consistent levels of taxation in the UK and Germany, expressed as a percentage of GDP. The exception is France, which added about 8 per cent of GDP to its tax take between 1975 and 1985. With respect to taxes on incomes and profits, the UK collects more than the other two as a percentage of GDP. Tax revenues and taxes on incomes and profits as a percentage of GDP are shown in Tables 2.10 and 2.11.

\section{Germany}

German federal fiscal policy treats the deficit as if some of it is 'structural' in the sense that the deficit does not clear at the peak of the economic cycle. There have been various attempts to hold back the demand on the social security and pension systems. The Kohl governments (1982-98) raised the retirement age, indexed pension increases to net rather than gross wage levels and undertook other adjustments to pension entitlements. Further efforts to cut spending included: reducing wage replacement rates for the unemployed; limiting social security payments to asylum seekers; and sick pay was reduced from 100 per cent to 80 per cent of normal earnings. 
Table 2.12 Public finances in Germany, 1970-2003

\begin{tabular}{lrrrr}
\hline$€ m$ & Expenditure & Revenue & $\begin{array}{r}\text { Financial } \\
\text { balance } \neq\end{array}$ & Net borrowing \\
\hline 1970 & 100,382 & 96,279 & $-4,081$ & 3,222 \\
1980 & 379,188 & 352,796 & $-26,505$ & 27,659 \\
1990 & 585,228 & 557,977 & $-27,147$ & 37,120 \\
$1991^{\dagger}$ & 721,855 & 667,840 & $-53,902$ & 58,663 \\
1992 & 827,636 & 765,032 & $-62,618$ & 55,414 \\
1993 & 866,052 & 797,472 & $-68,206$ & 67,809 \\
1994 & 909,381 & 850,885 & $-58,670$ & 46,426 \\
1995 & 950,523 & 889,492 & $-60,931$ & 48,970 \\
1996 & 962,546 & 894,310 & $-68,017$ & 56,855 \\
$1997^{*}$ & 961,220 & 916,520 & $-45,076$ & 50,987 \\
1997 & 921,798 & 876,581 & $-45,567$ & 50,848 \\
1998 & 932,704 & 906,549 & $-25,981$ & 32,705 \\
1999 & 951,294 & 929,935 & $-21,963$ & 31,747 \\
2000 & 960,788 & $979,322^{\S}$ & 18,552 & 19,763 \\
2001 & 975,465 & 925,600 & $-49,768$ & 6,532 \\
2002 & 987,072 & 920,353 & $-66,299$ & 45,467 \\
2003 & $1,000,980$ & 926,334 & $-74,487$ & 62,907 \\
\hline
\end{tabular}

Source: Federal Statistics Office, Germany (accessed 2004)

Key $\quad *$ Revenue less expenditure incl. internal offsetting. Not identical to government budget deficit in national accounts

TFrom 1991 data refer to the FRG post-3 October 1990

"In 1997 hospitals with commercial accounts and the supplementary funds for public employees were excluded from the accounts

\$Includes revenue from sale of mobile phone licences

At the same time, demands on spending continued to grow, especially through long-term care insurance for the elderly (introduced in 1994), continuing early retirements and wage subsidies designed to cut unemployment in the east.

In two of the biggest deficit years some of the deficit was partly caused by technical bad luck: the accounts for 1995 show debt service charges for the unification debt in the main government accounts for the first time, while in 1996 court rulings raised income tax thresholds and shifted mining subsidies from fuel bills to the government account.

Table 2.12 shows net borrowing growing again in 2003 , to $€ 62.9$ billion, of which $€ 38.6$ was accounted for by the Federal government. The 2004 budget estimated federal net borrowings of $€ 29.3$ but the likely out-turn was $€ 10$ billion higher than that partly because of lower than expected tax revenues and partly because of higher spending on labour market polices. 
Tax revenues were predicted to fall again in 2005 and thereafter recover through to 2008. Achieving the GSP level of deficit is heavily dependent on the tax revenue growth assumptions: +4 per cent in 2006 and +3.8 per cent in 2007 , with corresponding spending growth held to +1.8 per cent and +1.4 per cent. This is especially difficult given that income tax rates have been progressively reduced. Between 2000 and 2005 the top rate of tax was cut from 53 per cent to 42 per cent and the bottom rate from 26 per cent to 15 per cent (Agenda 20102004 ).

As Siebert has suggested: 'It is fair to say that the budget deficits are not caused by a spending spree... A major factor in the budget deficits is the poor showing of tax revenue' (2004: 38 ). The problem may be that the economic recovery (growth returned in the second half of 2003) did not result in a proportionate increase in tax revenues. If companies are more able to avoid corporate taxes, while the rates of income tax are cut, then the proportion of the deficit that is structural will increase and the government will not be able to reduce its deficit to the GSP prescribed level. Meanwhile, the government continues to prop up the current deficit with privatisation proceeds (Agenda 2010 2004). The German government finally reduced the deficit to 2.5 per cent of GDP in the second half of 2006 (Statistisches Bundesamt Deutschland 2006).

The German deficit was the product of a series of events: company restructuring produced a large number of redundancies of workers who became pensioners at an early age with large pensions; reunification without economic transformation in the east; tax cuts; and electoral resistance to benefit reductions. While there are efforts to contain entitlements, especially for the unemployed, there is as yet no sign of a dismantling of the welfare system.

\section{France}

Demands for spending have resulted in a persistent budget deficit that remains at 1.5-2 per cent of GDP even at the top of the economic cycle. The French deficit also follows the economic cycle. Figure 2.1 shows that the French cycle is roughly synchronised with the German, peaking in the mid1990s, then beginning to rise again after 2000. By 2002 the deficit had crossed the GSP threshold of 3 per cent of GDP and did so again in 2003.

In 2003 France received a mission from the International Monetary Fund for an Article IV consultation (International Monetary Fund 2003). The IMF approved of the French government's plans to cut the deficit in the medium term. In response to the problem of population ageing and the desirability of cutting taxes the IMF said that that the government should aim for a small structural surplus 'within the next five years' and cut the size of the outstanding debt. 


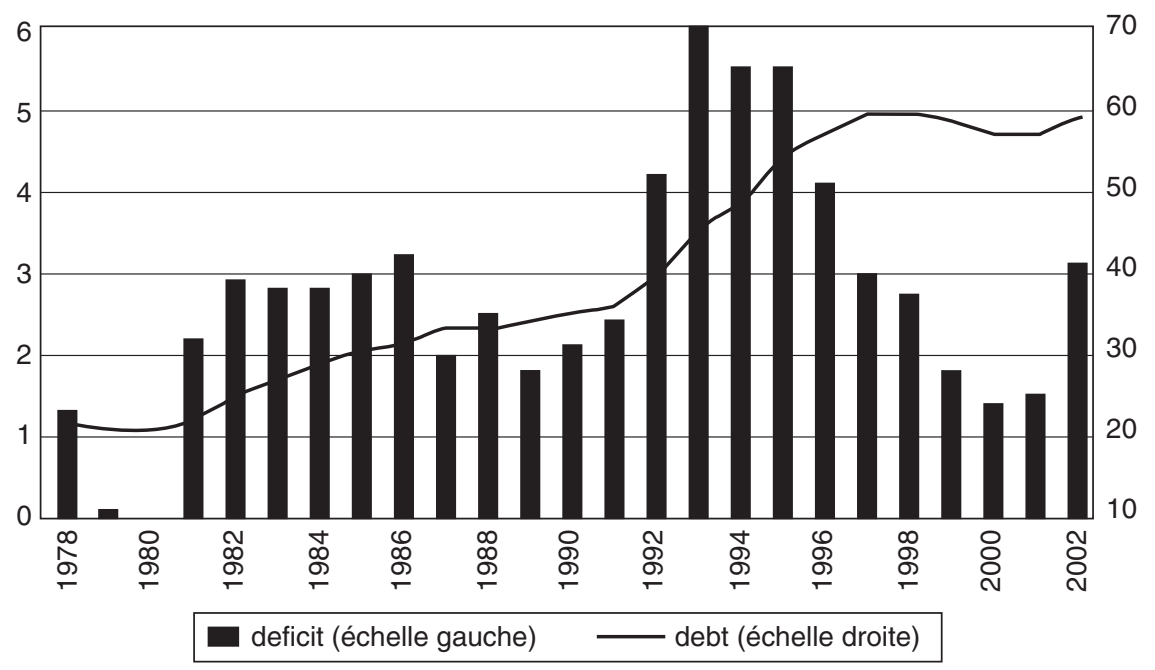

Figure 2.1 Evolution of the public sector deficit and the French public sector debt, 1978-2002, as a percentage of GDP

Source: Ministry of Finance 2003

Key échelle gauche $=$ left-hand scale; échelle droite $=$ right-hand scale

The 2005 French budget started the process of expenditure cuts to conform to the GSP target of a deficit of less than 3 per cent of GDP. The outgoing Minister of Finance, Nicolas Sarkozy, introduced the biggest deficit reduction in a single year that had ever been achieved, from $€ 57 \mathrm{bn}$ in 2003 to $€ 45 \mathrm{bn}$ in 2005 , or 2.9 per cent of GDP, just within the GSP threshold. The main features of the budget were a ritual net cut of 7,188 civil service and public sector jobs and sweeteners of $€ 2$ billion in tax cuts, $€ 0.9$ billion to households and $€ 1.1$ billion to companies. The reduction of the deficit relied on two factors: an economic growth rate of 2.5 per cent in 2004 and 2005 (compared with a eurozone forecast of 1.9 per cent and 2.2 per cent) to raise the level of taxes collected; and a one-off windfall of $€ 7$ billion from the transfer of the EDF and GDF (the electricity and gas companies) pension funds to the social security fund, a sum amounting to 0.4 per cent of GDP. Without this windfall, the projected deficit for 2005 would have been 3.3 per cent of GDP (Le Monde, 22 September 2004). The 2005 budget also introduced some selective tax cuts, reducing the top rate of income tax from 49.58 per cent to 48.09 per cent, increasing tax allowances for home workers and for social security claimants who find jobs, and used tax levels to cut smoking and driving.

The persistent French deficit from 2003 was the product of a fall in the amount of tax collected and an increase in spending, especially on health 
and social security. In 2002, the increase in the social security fund deficit added 0.3 per cent of GDP to the budget. The following year, the deficit on the health insurance budget increased from $€ 6.1 \mathrm{bn}$ to $€ 10.6 \mathrm{bn}$, mainly because of growth in prescribed medicines and general use of healthcare. The government changed both social security and health insurance systems to try to get spending under control. The Council of the European Union closed the deficit procedure in January 2007, announcing that the deficit had finally fallen below 3 per cent of GDP (Council of European Union 2007).

On the definition of structural deficit related to the deficit at the top of the cycle, the French government probably has roughly a 2 per cent structural deficit and a 1-2 per cent cyclical deficit in recession. Demographic trends and the likelihood of persistent unemployment imply a demand for a steady increase in benefit payments at existing levels and entitlement definitions. Unless taxes are raised in proportion, the deficit will return. Gradual reductions in entitlements and benefit levels are the other option to contain the deficit. However, as in Germany, the number of voters who stand to lose from lengthening working life and reducing benefits is large and resistance likely.

\section{United Kingdom}

Table 2.13 shows UK public sector receipts and expenditure from 1970 to 2002. There is a cyclical pattern to the deficit and a consistent surplus was recorded by the Labour government from 1997/8 onwards. This allowed the chancellor to pay off debts and reduce the outstanding debt and current debt payments. In 2002/3 (beyond the table) the account went into deficit for the first time since 1997. Between April and October the public sector recorded a deficit of $£ 17.2$ billion (Office for National Statistics 2004).

The UK government increased public spending up to 2007, especially on services rather than benefits. Its deficit is just within the GSP criteria. Increased spending, especially on education and healthcare, indicates a move towards more European norms, rather than away from those values.

These trends therefore show: there are cyclical variations in budget deficits in all three countries; that Germany and France both seem to have structural deficits that do not clear at the top of the cycle; and that the French and German governments, while taking steps to reduce deficits, have other priorities than a balanced budget, whatever the Maastricht Treaty requirements might be. The UK has cyclical deficits but attempts to balance the government budget over a whole economic cycle. What the trends do not show is evidence of a big 'fiscal crisis of the state' or a need to dismantle social policies in a radical way. 
Table 2.13 United Kingdom, public sector receipts and expenditure, 1970-2002 (fm)

\begin{tabular}{lccc}
\hline Year & Current expenditure & Current receipts & Receipts less expenditure \\
\hline 1970 & 16,899 & 22,618 & 5,719 \\
1980 & 92,567 & 97,639 & 5,072 \\
1990 & 199,716 & 218,255 & 18,539 \\
1991 & 220,980 & 225,729 & 4,749 \\
1992 & 244,221 & 227,629 & $-16,592$ \\
1993 & 258,163 & 230,508 & $-27,655$ \\
1994 & 272,463 & 249,416 & $-23,047$ \\
1995 & 285,489 & 270,247 & $-15,242$ \\
1996 & 294,167 & 283,839 & $-10,328$ \\
1997 & 304,370 & 305,026 & 656 \\
1998 & 312,153 & 331,850 & 19,697 \\
1999 & 322,871 & 350,412 & 27,541 \\
2000 & 342,878 & 375,043 & 32,165 \\
2001 & 361,533 & 391,118 & 29,585 \\
2002 & 385,940 & 393,925 & 7,985 \\
\hline
\end{tabular}

Source: Office for National Statistics 2004

\section{Global competition, the competitive state and economic performance}

The picture presented above is one of variation in social spending and variation in the size of the public sector deficit, although all three countries operate within a shared, broadly social democratic framework. In this section we look briefly at differences in economic performance: the question is whether the less generous levels of social benefits, and relative fiscal prudence, have generated better economic performance in the United Kingdom than in its two main European competitors.

\section{Trade competitiveness}

The first set of evidence focuses on trade competitiveness. Trade statistics are available on the WTO database. Table 2.14 shows imports and exports of merchandise and services for the world's biggest trading countries in 2003. The data show that the USA is the world's biggest exporter of the sum of merchandise and services, followed by Germany, Japan, China, France and the UK. In merchandise exports, Germany is ranked first, followed by the USA, with France fifth and the UK sixth. For service exports (mainly banking and insurance) the UK is second after the USA, Germany third and France fourth. Germany's merchandise exports are 236 per cent of those of the UK and nearly twice as big as France's. Germany's problems of inflexibility and high tax are not yet reflected in a poor balance of payments performance. 


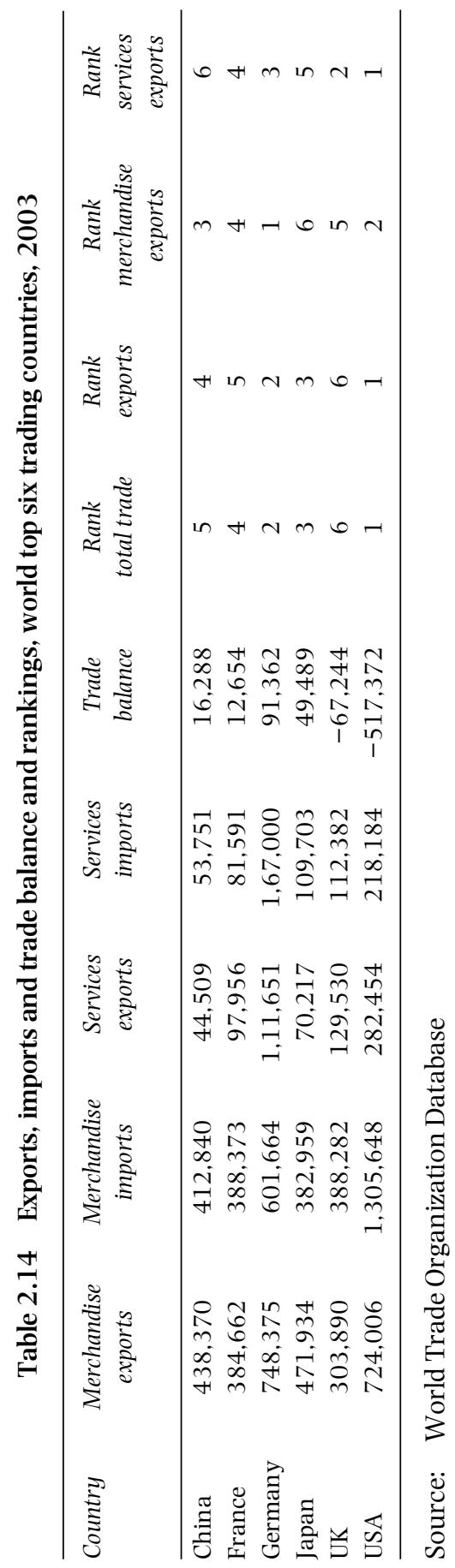


Table 2.15 GDP and GDP per head, 2003

\begin{tabular}{lcrrrc}
\hline & & UK & France & Germany & Unit \\
\hline Eurostat & GDP/head & 26,490 & 25,280 & 24,080 & Euro \\
OECD & GDP & 1,720 & 1,709 & 2,171 & $\begin{array}{c}\text { \$US at purchasing } \\
\text { power parity }\end{array}$ \\
OECD & GDP/head & 29,000 & 27,800 & 26,300 & \$US \\
\hline
\end{tabular}

Sources: Eurostat Yearbook 2004 and OECD in Figures 2004

These merchandise export figures do not show a picture of a sluggish Germany and France and a nimble, flexible UK. It is also unlikely that the positive UK performance in banking and insurance exports is a result of a flexible labour market and the low costs of employing banking and insurance labour.

If we look at trade balance, Germany had a healthy surplus, at 10 per cent of exports; France had a positive balance of 2.6 per cent of exports; the UK had a trade deficit of 15.5 per cent of the value of exports.

\section{Gross Domestic Product}

A common measure of economic performance is the size and growth rate of Gross Domestic Product (GDP), measured both by the value of goods and services produced and the value of incomes derived from producing them. Comparative GDP suffers from the problem of how national currencies are valued. One solution to this is to measure in common purchasing powerwhat the incomes could buy, rather than converting them at the exchange rate.

As shown in Table 2.15, the GDP figure puts the UK a whisker ahead of France, making the UK the fourth biggest economy on this measure (after the USA, Japan and Germany). For GDP per head the three countries are very close, with the UK ahead of France and Germany according to both sources. However, the UK had faster GDP growth in the decade to 2003, as shown in table 2.16. By 2008, UK GDP per head was estimated by Oxford Economics (2008) to be $£ 23,500$, France $£ 21,700$ and Germany $£ 21,665$. This contrasts with 1974, when UK GDP per head was 83 per cent of that of France and 96 per cent that of Germany.

\section{Direct investment flows}

The argument about tax levels and investment is that low tax attracts inward investment (and encourages domestic investment). A "competitive state' takes notice of the impact of taxation decisions on companies' investment location decisions. 
Table 2.16 Average annual volume change in GDP as a percentage, 1993-2003

\begin{tabular}{ccc}
\hline France & Germany & UK \\
\hline 2.1 & 1.4 & 2.9 \\
\hline
\end{tabular}

Source: OECD 2004a

Table 2.17 Investment flows, 1993 and 2003

\begin{tabular}{|c|c|c|c|c|c|c|c|}
\hline & & $\begin{array}{c}\text { Billion } \\
\text { \$US }\end{array}$ & $\%$ GDP & $\begin{array}{c}\text { Billion } \\
\$ U S\end{array}$ & $\%$ GDP & $\begin{array}{c}\text { Billion } \\
\$ U S\end{array}$ & $\%$ GDP \\
\hline & & \multicolumn{2}{|c|}{ UK } & \multicolumn{2}{|c|}{ France } & \multicolumn{2}{|c|}{ Germany } \\
\hline \multirow[t]{2}{*}{ Inflows } & 1993 & 14.8 & 1.54 & 16.4 & 1.29 & 0.4 & 0.02 \\
\hline & 2003 & 14.6 & 0.81 & 45.3 & 2.6 & 12.9 & 0.54 \\
\hline \multirow[t]{2}{*}{ Outflows } & 1993 & 26.1 & 2.71 & 19.7 & 1.55 & 17.2 & 0.88 \\
\hline & 2003 & 55.3 & 3.08 & 55.2 & 3.17 & 2.6 & 0.11 \\
\hline
\end{tabular}

Source: OECD 2004a

Table 2.17 shows investment inflows and outflows of the three countries in 1993 and 2003. Clearly the UK and France had a net outflow of direct investment in both years. Germany has small flows in both directions. In 2003 France had more than three times the volume of direct inward investment than the United Kingdom. Also notable in Table 2.17 is the contrast between the large outflows of investment from the United Kingdom and France and the very small outflow from Germany. This probably reflects high levels of portfolio investment from the UK and investment in infrastructure by French public utility companies, while German profits are reinvested in Germany.

\section{Manufacturing output}

Statisticsshow that since 1997 manufacturing outputinFranceandGermany diverged from that of the UK. While output in all three countries declined after 2000 , the decline was faster in the UK than in the other two. Is this a paradox? The economy that responds to global pressure by keeping taxes and benefits low is the least successful in maintaining its manufacturing sector?

\section{Productivity and working hours}

Table 2.18 shows that the high GDP per head is partly due to the fact that more people are working in the UK, especially workers over 55 years old. Those in work also work longer hours. Table 2.18 shows the average hours worked per person in employment. UK workers of working age put in about 
Table 2.18 Hours worked per person in employment, 2002

\begin{tabular}{lccc}
\hline & UK & France & Germany \\
\hline All workers & 1707 & 1459 & 1444 \\
Workers 15-64 & 1221 & 946 & 934 \\
\hline
\end{tabular}

Source: Metz et al. 2004

Table 2.19 Productivity, 2002

\begin{tabular}{lccc}
\hline & UK & France & Germany \\
\hline GDP per worker & 100 & 112.9 & 98.8 \\
GDP per hour worked & 100 & 131.7 & 116.4 \\
\hline
\end{tabular}

Source: $\quad$ Metz et al. 2004

Table 2.20 Labour costs, euros per hour, 2004

\begin{tabular}{lcc}
\hline & Industry & Services \\
\hline Germany & 30.23 & 24.07 \\
France & 26.90 & 30.60 \\
UK & 24.99 & 24.45 \\
\hline
\end{tabular}

Source: European Commission 2006

30 per cent more hours than their French and German counterparts. Both France and Germany have policies of reducing working hours as a way of combating unemployment and hours worked have fallen since 2000.

Table 2.19 shows indices of productivity: GDP per worker and GDP per hour worked. While UK workers put in more hours, the value of their output per hour worked is probably 30 per cent less than that of their French counterparts and 16 per cent less than the Germans. One interpretation of these figures is that unemployment in France and Germany would reduce to UK levels if German and French workers were much less productive and willing to work longer hours for lower pay. In other words the employment 'success' of the UK is underpinned by low productivity combined with low pay. Table 2.20 shows comparative labour costs in manufacturing and services in the three countries in 2004: the UK is lowest in manufacturing and roughly the same as Germany in services.

\section{Conclusions}

The twin perils of globalised competition and population ageing may prove damaging to European welfare states, but up to now there has been no 
event that could be called a crisis. France and Germany have relatively high unemployment and structural fiscal deficits and both governments are attempting adjustments to their welfare regimes and labour markets to enable both unemployment and deficit levels to be lowered. The UK has a less generous welfare state and more flexible labour market than either France or Germany, but its workers put in an average of 30 per cent more hours and are on average 20 per cent less productive than their French and German counterparts. In both unemployment and retirement their benefits are significantly less generous that those of their European neighbours.

In economic performance, the UK has faster GDP growth and higher GDP per head from 2003, but also has a much larger net outflow of investment than France or Germany and a big negative trade balance, compared with the trade surpluses of France and Germany. The policy of low taxation and low benefits has not resulted in big net inflows of investment, nor a more successful trading economy.

What are the implications for the future of the social democratic project in these three countries? The settlement between capital, labour and the state can no longer, if it ever could, deliver social solidarity, wage restraint and a regulatory environment favourable to national capital. The freer movement of both capital and labour and the competition from nonwelfare states in industrial products clearly have an impact on the ability for national bargains to hold. However, the trends of the three decades from 1970 are surprising not because of the collapse of the social democratic model but because of its persistence. There are three reasons why the European model has not yet collapsed. First, the persistent competitiveness of manufacturing industry in France and Germany (along with other European social democracies) and some service sectors in the UK have enabled businesses in the successful sectors to continue to pay taxes and not participate in a 'race to the bottom' in wage levels or taxes. Second, the EU still provides protection for European business against completely free competition from low-wage economies, both in agricultural produce and manufactured goods. Third, the high levels of GDP per head leave room for bargaining over the distribution of that income among wages, profits and taxes. While the balance among these three will vary over time and according to the relative bargaining strengths of capital and labour, as we have seen in this chapter, pressures from global capital, commodity and labour flows have not yet, at least, tipped the balance entirely towards capital.

\section{Notes}

1 The German word I have translated as 'poverty-sharing' is Notgemeinschaft.

2 Süddeutsche Zeitung, 187, August 2004, author's translation. 
3 Figures for 2003, from OECD 2004a, Table 8.

4 In addition, there are means-tested benefits.

5 In the forty years to 2000, the US government had an average deficit of 2 per cent, for example (Schick 2000).

\section{References}

Agenda 2010 (2004) (German Federal Government, English translation).

Bongaarts, J. (2004) Population Aging and the Rising Cost of Public Pensions (Geneva: Population Council, Working Paper No. 185).

Council of European Union (2007) press release, 30 January.

Esping-Anderson, G. (1990) The Three Worlds of Welfare Capitalism (Princeton: Princeton University Press).

European Commission (2006) Key Figures on Europe (Brussels: Europe Commission).

Eurostat (2004) Eurostat Yearbook, the Statistical Guide to Europe (Brussels: Eurostat).

Federal Statistics Office, Germany (Statistisches Bundesamt): www.destatis.de.

International Monetary Fund (2003) France: 2003 Article IV Consultation Concluding Statement of the Mission, 30 June.

Kitschelt, H. and Streeck, W. (2004) Germany: Beyond the Stable State (London: Frank Cass).

Metz, R., Riley, R. and Weale, M. (2004) 'Economic performance in France, Germany and the United Kingdom: 1997-2002', National Institute Economic Review, 188, April.

Ministry of France (2003) 'Dépenses Publiques et déficit Fiscale' Paris: Documentation Française.

OECD (2004a) OECD in Figures.

OECD (2004b) Economic Outlook, 75.

OECD Database: www.sourceoecd.org.

Office for National Statistics (2004) Selected Financial Statistics, 5.4.

Oxford Economics (2008) 'UK GDP per capita to overtake US in 2008 for first time since the 19th century', press release, 7 January.

Schick, A. (2000) The Federal Budget: Politics, Policy, Process (Washington, DC: Brookings Institution Press).

Siebert, H. (2004) Germany's Fiscal Policy Stance, Kiel Working Paper 1196, (Kiel: Institute for World Economics).

Smith, T. B. (2004) France in Crisis (Cambridge: Cambridge University Press).

Statistisches Bundesamt Deutschland (2006) press release, 15 July: www.destatis. de.

World Trade Organization Database: http://stat.wto.org.

Zoom (2003) 'European and international unemployment systems: trends and development, status report as at 31.12.2002': http://info.assedic.fr/assurance_ chomage/travail/documents/ZOOM2003-Angl.241-348.pdf. 